\title{
EFFECT OF INCREASED CONTENT OF ANIMAL PROTEIN IN FEED MIXTURES BASED ON EXTRUDED RICE ON REARING PERFORMANCE AND BLOOD PARAMETERS OF PIGLETS
}

\author{
Anna Czech $^{1 \star}$, Jerzy Pastuszak², Grażyna Kusior ${ }^{1}$ \\ ${ }^{1}$ Department of Biochemistry and Toxicology, University of Life Sciences in Lublin, Akademicka 13, \\ 20-934 Lublin, Poland \\ ${ }^{2}$ Etos Czesław Szymendera, Katowicka 83c/105, 61-131 Poznań, Poland \\ •Corresponding author: annaczech@poczta.fm
}

\begin{abstract}
The aim of this study was to compare the effects of three feed mixtures based on various feed components, including extruded rice, and differing in the source and level of animal protein on rearing performance and biochemical and haematological blood parameters of piglets in the peri-weaning period. The experiments covered 96 piglets, crosses of PIC hybrid sows with a P76 boar that were divided into three experimental groups. The piglets from group I received a prestarter diet based on extruded wheat and protein of both plant and animal origin, whilst those from groups II and III were fed prestarter diets containing: group II - extruded rice (protein as in group I), and group III - extruded rice with protein components of exclusively animal origin. The addition of extruded rice and the increased content of animal protein in feed mixture improved the rearing performance of piglets (higher body weight gains and more efficient feed conversion ratio). The feeding of piglets with the diets containing extruded rice and increased animal protein components (III group) was also observed to stimulate lipid metabolism, which resulted in reduced plasma levels of LDL-cholesterol and in increased percentage of HDL-cholesterol, which contributed to increased blood levels of urea compared to the other experimental groups.
\end{abstract}

Key words: piglets, rice, blood, haematology, biochemistry, production indices, animal protein

During the period around weaning, piglets still have an undeveloped digestive system and for this reason they often suffer from digestive disorders, including diarrhoea (Pluske and Hampson, 2005). Undigested feed may increase the osmotic pressure, but it may also constitute a perfect medium for the growth of pathogenic bacteria (Zhen-Ping et al., 2008). To achieve better production results, diets for piglets in this period should ensure optimal levels of required nutrients. In recent years, the 
interest of many scientists has been focused on rice, especially on rice subjected to barothermal treatment and characterized by significantly higher flavour preferences (Vicente et al., 2008). According to Peiniau et al. (1996) and Vente-Spreeuwenberg et al. (2004), a significant role in piglet feeding is also ascribed to the appropriate selection of protein components, which are implicated to increase feed conversion ratio, improve body weight gains and protein digestibility, as well as enhance pancreatic protease activity. High protein digestibility is typical of fish meal, casein or spray-dried blood plasma (SDBP) administration. Bikker et al. (2004) report, however, that the positive effect of SDBP addition to feed mixtures for piglets is mainly observed in the first week after weaning.

To date, research has mainly been focused on effects of supplementing feed mixtures with extruded rice together with protein of plant and animal origin (meat-andbone meal, blood meal, fish meal), whereas no studies have been performed on the concomitant administration of extruded rice and blood plasma. It seems interesting, therefore, to develop - by way of selecting the best variant - a feed mixture that would assure a high feed intake and high feed conversion ratio as well as yielding positive health effects on piglets due to its tastiness and functional properties of its components.

The aim of this study was to compare effects of three feed mixtures based on various feed components, including extruded rice, and differing in the source and level of animal protein on rearing performance and biochemical and haematological blood parameters of piglets in the periweaning period.

\section{Material and methods}

\section{Experimental diets}

Experiments were conducted on 96 piglets, crosses of PIC hybrid sows with a P76 boar that were divided into three groups and fed cereal-based feed mixtures containing different protein components. Feed mixture formulations were presented in Table 1. Contents of nutrients in all feed mixtures were consistent with Nutrient Requirements of Swine (NRC, 1998) (Table 2). The feed mixtures were administered ad libitum with constant access to drinking water.

Piglets from group I received a prestarter diet based on extruded wheat, whereas those from groups II and III were fed prestarter diets containing: group II - extruded rice, and group III - extruded rice with protein components of animal origin. Each group included thirty-two piglets that were tagged and housed in pens, 4 piglets each (eight pens per group).

\section{Analytical procedures}

In the study period, blood was sampled twice from the jugular vein of all piglets on days 28 and 51 of age to 10 -ml heparinized tubes; the sampling was supervised by a veterinarian. The animals were fasted for $12 \mathrm{~h}$ prior to blood sampling. 
Table 1. Composition of piglet feed mixtures (\%)

\begin{tabular}{l|c|c|c}
\hline \multirow{2}{*}{\multicolumn{1}{c}{ Item }} & \multicolumn{3}{c}{ Feeding groups } \\
\cline { 2 - 4 } & I & II & III \\
\hline Extruded rice & & 56.54 & 63.57 \\
Extruded wheat & 65.93 & & \\
Soybean meal Hypro & & 4.86 & \\
Soybean, toasted & 12.00 & 16.00 & 10.16 \\
Fish meal & 5.00 & 5.00 & 9.92 \\
Sweet whey powder & 9.92 & 9.92 & 3.08 \\
Dried haemoglobin & & & 4.00 \\
Plasma, spray-dried & 2.00 & 2.00 & 6.85 \\
Soya oil & 1.58 & 2.26 & 0.66 \\
Monocalcium phosphate & 0.44 & 0.80 & 0.26 \\
Calcium formate & 0.82 & 0.61 & \\
NaCl & 0.24 & 0.20 & 0.13 \\
L-lysine HCl & 0.55 & 0.36 & 0.15 \\
DL-methionine & 0.20 & 0.18 & 0.18 \\
L-threonine & 0.28 & 0.23 & 0.05 \\
DL-tryptophan & 0.04 & 0.04 & 0.50 \\
Formic acid/propionic acid 66/34 & 0.50 & 0.50 & 0.50 \\
* Vitamin and mineral premix $0.05 \%$ & 0.50 & 0.50 & \\
\hline
\end{tabular}

*Content of minerals and vitamins in $1 \mathrm{~kg}$ mixtures: vitamin A 15000 i.u., vitamin D3 2000 i.u, vitamin E $150 \mathrm{mg}$, vitamin K3 $4.5 \mathrm{mg}$, vitamin B1 $3 \mathrm{mg}$, vitamin B2 $6 \mathrm{mg}$, vitamin B6 $4 \mathrm{mg}$, vitamin B12 $30 \mu \mathrm{g}$, biotin 150 $\mu \mathrm{g}$, Ca pantothenate $15 \mathrm{mg}$, nicotinic acid $30 \mathrm{mg}$, folic acid $2 \mathrm{mg}, \mathrm{Fe} 120 \mathrm{mg}$, Mn $50 \mathrm{mg}, \mathrm{Cu} 150 \mathrm{mg}, \mathrm{Zn} 120$ $\mathrm{mg}$, I $0.8 \mathrm{mg}$, Co $0.4 \mathrm{mg}$, Se $0.40 \mathrm{mg}$.

Table 2. Basic nutrients and metabolizable energy in feed mixtures

\begin{tabular}{l|c|c|c}
\hline \multirow{2}{*}{\multicolumn{1}{c|}{ Item }} & \multicolumn{3}{c}{ Feeding groups } \\
\cline { 2 - 4 } & I & II & III \\
\hline Metabolizable energy $\left(\mathrm{MJ} \mathrm{kg}^{-1}\right)$ & 13.90 & 14.09 & 14.49 \\
In 1 kg of mixture: & & & \\
$\quad$ total protein (g) & 191.9 & 189.8 & 190.8 \\
crude fat $(\mathrm{g})$ & 57.8 & 68.81 & 86.71 \\
crude fibre (g) & 26.1 & 15.9 & 5.69 \\
calcium (g) & 7.03 & 7.10 & 7.02 \\
total phosphorus $(\mathrm{g})$ & 6.11 & 6.06 & 6.09 \\
sodium $(\mathrm{g})$ & 2.63 & 2.58 & 2.98 \\
\hline
\end{tabular}

Samples of feed mixtures were collected twice following the Polish Standard PN-87/C-04288/03 and analysed for their chemical composition, including basic nutrients: dry matter, crude ash - according to the Polish Standard, total nitrogen - with the Kjeldahl's method following the Polish Standard PN-75/A-04018, ether extract - according to the Polish Standard PN-76/R-64753 with the Soxhlet's method, and crude fibre - according to IN-04-FOSS standard. The feed mixtures were also analysed for the contents of total phosphorus (according to Polish Standard PN-76/R64781), calcium and sodium (using the AAS method). 
Haematological markers, including: haematocrit number $(\mathrm{Ht})$, haemoglobin content $(\mathrm{Hb})$, red blood cells number $(\mathrm{RBC})$, white blood cells number (WBC), and percentage composition of leucocytes (leucogram), were assayed in whole blood using the ABACUS-Vet apparatus. Blood plasma was analysed with the colorimetric methods, using Cormay monotests, for the contents of: total protein (TP), glucose (GLU), triacylglycerols (TG), uric acid (UA), urea (UREA), total cholesterol (CHOL), high-density lipoprotein fraction of cholesterol (HDL), and for activities of: alanine aminotransferase (ALT) and aspartate aminotransferase (AST). The content of the low-density lipoprotein fraction of cholesterol (LDL) was computed from the formula provided by Friedewald et al. (1970):

$$
\text { LDL }(\text { mmol l-1) }=\text { total cholesterol }-H D L-\text { triglycerides } / 2.2
$$

Rearing performance was analysed throughout the experiment based on body weight of the piglets at 3, 28 (weaning) and 51 days of age, feed conversion ratio or feed intake, and health status of the animals. The piglets were weighed individually. The health status of animals was monitored, and feed intake was controlled quantitatively during the experimental period.

\section{Statistical analysis}

The numerical data were subjected to a statistical analysis with Statistica ver. 5 software, using one-way analysis of variance (ANOVA), assuming significance levels of 0.05 and 0.01 .

\section{Results}

At the beginning of the experiment the mean body weight of the piglets from particular experimental groups was similar and averaged $1.66 \pm 0.02 \mathrm{~kg}$ (Table 3 ). The lowest body weight gains (ADG) were noted in piglets receiving the feed mixture with extruded wheat (group I). Body weight gains of the animals from group II were higher by approx. 13\% compared to group I. Finally, significantly $(\mathrm{P} \leq 0.05)$ higher daily feed intake (by approx. 32\%) was determined in groups II and III, compared to group I (Table 3).

Table 3. Daily gains, feed intake and FCR

\begin{tabular}{l|c|c|c}
\hline \multirow{2}{*}{ Item } & \multicolumn{3}{|c}{ Feeding groups } \\
\cline { 2 - 4 } & \multicolumn{4}{c}{ I } & III \\
\hline BW (kg) & & & \\
day of age: & $1.68 \pm 0.45$ & $1.67 \pm 0.22$ & $1.63 \pm 0.34$ \\
3 & $7.39 \pm 0.67$ & $6.89 \pm 0.65$ & $7.05 \pm 0.48$ \\
28 & $13.41 \mathrm{a} \pm 1.01$ & $14.89 \mathrm{~b} \pm 0.67$ & $14.13 \mathrm{~b} \pm 0.73$ \\
51 & $244 \mathrm{~b}$ & $275 \mathrm{a}$ & $260 \mathrm{ab}$ \\
ADG, 3-51 days (g) & $360 \mathrm{~b}$ & $525 \mathrm{a}$ & $544 \mathrm{a}$ \\
Feed intake, 3-51 days (g) & $1.47 \mathrm{~b}$ & $1.91 \mathrm{ab}$ & $2,09 \mathrm{a}$ \\
FCR (g/g) & &
\end{tabular}

$\mathrm{a}, \mathrm{b}, \mathrm{c}-$ values in the same rows with different letters differ significantly at $\mathrm{P} \leq 0.05$. 
The haematological blood markers (RBC, HB, HT) of the piglets were consistent with values reported by Friendship and Henry (1996) for piglets and by Klem et al. (2010) for growing pigs (Table 4). The piglets from group I were characterized by slightly higher values of erythrocyte markers. In the case of erythrocyte number (assayed on day 51 of age and as mean RBC count) the difference was statistically significant $(\mathrm{P} \leq 0.05)$ when compared to group III (Table 4). Values of leukocyte markers also fell within reference values provided by Friendship and Henry (1996) and Klem et al. (2010) (Table 4). In the reported experiment, mean counts of WBC and NEU in the piglets from group I were significantly higher than in the animals from the other experimental groups (II and III). An opposite relationship was noted for the lymphocyte count (LYM).

Table 4. Content of haematological parameters in plasma of piglets

\begin{tabular}{|c|c|c|c|c|c|}
\hline \multirow{2}{*}{ Item } & \multirow{2}{*}{ Day of age } & \multicolumn{3}{|c|}{ Feeding groups } & \multirow{2}{*}{ P-value } \\
\hline & & I & II & III & \\
\hline $\mathrm{RBC}$ & 28 & $5.08 \pm 0.86$ & $4.93 \pm 0.77$ & $4.67 \pm 0.84$ & 0.071 \\
\hline $10^{12} 1^{-1}$ & 51 & $6.82 \mathrm{a} \pm 0.90$ & $6.32 \mathrm{ab} \pm 0.29$ & $5.91 \mathrm{~b} \pm 0.02$ & 0.042 \\
\hline$\overline{\mathrm{x}}$ & & $5.95 \mathrm{a} \pm 0.88$ & $5.63 \mathrm{ab} \pm 0.53$ & $5.29 \mathrm{~b} \pm 0.43$ & 0.044 \\
\hline $\mathrm{Hb}$ & 28 & $4.61 \mathrm{a} \pm 0.37$ & $3.83 \mathrm{~b} \pm 0.36$ & $4.24 \mathrm{ab} \pm 0.28$ & 0.033 \\
\hline $\mathrm{mmol} \mathrm{l}^{-1}$ & 51 & $8.26 \pm 0.30$ & $8.42 \pm 0.84$ & $8.53 \pm 0.21$ & 0.089 \\
\hline$\overline{\mathrm{x}}$ & & $6,44 \pm 0.34$ & $6.13 \pm 0.60$ & $6.39 \pm 0.25$ & 0.057 \\
\hline $\mathrm{Ht}$ & 28 & $24.88 \pm 2.70$ & $20.00 \pm 1.57$ & $22.28 \pm 1.95$ & 0.083 \\
\hline$\%$ & 51 & $39.49 \pm 0.53$ & $41.29 \pm 3.07$ & $40.90 \pm 1.00$ & 0.065 \\
\hline$\overline{\mathrm{x}}$ & & $32.19 \pm 2.70$ & $30.65 \pm 2.32$ & $31.59 \pm 1.48$ & 0.089 \\
\hline WBC & 28 & $17.63 \mathrm{~b} \pm 2.52$ & $11.31 \mathrm{a} \pm 1.09$ & $15.25 \mathrm{~b} \pm 1.76$ & 0.011 \\
\hline $10^{9} \mathrm{l}^{-1}$ & 51 & $22.58 \mathrm{~b} \pm 0.45$ & $20.38 \mathrm{a} \pm 4.66$ & $17.37 \mathrm{a} \pm 2.06$ & 0.016 \\
\hline$\overline{\mathrm{x}}$ & & $20.11 \mathrm{~b} \pm 1.49$ & $15.85 \mathrm{a} \pm 2.88$ & $16.31 \mathrm{a} \pm 1.91$ & 0.037 \\
\hline LYM & 28 & $65.12 \pm 3.39$ & $65.73 \pm 1.41$ & $66.88 \pm 1.05$ & 0.099 \\
\hline$\%$ & 51 & $38.19 \mathrm{a} \pm 2.93$ & $52.80 \mathrm{~b} \pm 0.43$ & $56.57 \mathrm{~b} \pm 2.83$ & 0.036 \\
\hline$\overline{\mathrm{x}}$ & & $51.66 \mathrm{a} \pm 3.16$ & $59.27 \mathrm{~b} \pm 0.92$ & $61.73 \mathrm{~b} \pm 1.94$ & 0.045 \\
\hline MID & 28 & $3.03 \mathrm{~b} \pm 0.64$ & $1.72 \mathrm{a} \pm 0.21$ & $2.78 \mathrm{~b} \pm 0.75$ & 0.039 \\
\hline$\%$ & 51 & $5.00 \mathrm{~b} \pm 0.25$ & $0.88 \mathrm{a} \pm 0.38$ & $4.13 \mathrm{~b} \pm 0.75$ & 0.024 \\
\hline$\overline{\mathrm{x}}$ & & $4,02 \mathrm{~b} \pm 0.45$ & $1.30 \mathrm{a} \pm 0.30$ & $3.46 \mathrm{~b} \pm 0.75$ & 0.033 \\
\hline NEU & 28 & $31.85 \pm 4.45$ & $32.55 \pm 2.18$ & $30.35 \pm 1.48$ & 0.092 \\
\hline$\%$ & 51 & $56.81 \mathrm{~b} \pm 5.38$ & $46.33 \mathrm{a} \pm 0.72$ & $39.30 \mathrm{a} \pm 2.08$ & 0.041 \\
\hline$\overline{\mathrm{x}}$ & & $44.33 \mathrm{~b} \pm 4.92$ & $39.44 \mathrm{a} \pm 1.45$ & $34.83 \mathrm{a} \pm 1.78$ & 0.048 \\
\hline
\end{tabular}

$\mathrm{a}, \mathrm{b}$ - values in the same rows with different letters differ significantly at $\mathrm{P} \leq 0.05$.

The lipid parameters of blood, i.e. total cholesterol, HDL cholesterol, and LDL cholesterol, differed significantly in piglets from particular experimental groups, but were in agreement with the reference values provided by Friendship and Henry (1996) and Klem et al. (2010) (Table 5). On both day 28 and 51 of age, piglets from group I were characterized by a significantly lower content of CHOL in blood 
plasma, compared to the animals from group II (on day 28) and group III (on day 51 of age) (Table 5). In contrast, no differences were demonstrated between the experimental animals in the mean plasma level of CHOL.

Table 5. Content of lipid parameters in plasma of piglets

\begin{tabular}{|c|c|c|c|c|c|}
\hline \multirow[b]{2}{*}{ Item } & \multirow{2}{*}{$\begin{array}{c}\text { Day of } \\
\text { age }\end{array}$} & \multicolumn{3}{|c|}{ Feeding groups } & \multirow[b]{2}{*}{ P-value } \\
\hline & & I & II & III & \\
\hline \multirow{2}{*}{$\begin{array}{l}\text { CHOL } \\
\mathrm{mmol} \mathrm{l}^{-1}\end{array}$} & 28 & $2.83 \mathrm{a} \pm 0.27$ & $3.45 \mathrm{~b} \pm 0.95$ & $2.68 \mathrm{a} \pm 0.62$ & 0.042 \\
\hline & 51 & $2.03 \mathrm{a} \pm 0.20$ & $1.71 \mathrm{a} \pm 0.36$ & $2.28 \mathrm{~b} \pm 0.41$ & 0.034 \\
\hline$\overline{\mathrm{x}}$ & & $2.43 \pm 0.24$ & $2.58 \pm 0.66$ & $2.48 \pm 0.52$ & 0.067 \\
\hline \multirow{2}{*}{$\begin{array}{l}\mathrm{TG} \\
\mathrm{mmol} \mathrm{l}^{-1}\end{array}$} & 28 & $0.95 \mathrm{ab} \pm 0.14$ & $0.72 \mathrm{a} \pm 0.11$ & $1.36 \mathrm{~b} \pm 0.64$ & 0.041 \\
\hline & 51 & $0.44 \mathrm{~b} \pm 0.12$ & $0.36 \mathrm{a} \pm 0.04$ & $0.47 \mathrm{~b} \pm 0.03$ & 0.046 \\
\hline$\overline{\mathrm{x}}$ & & $0.70 \mathrm{ab} \pm 0.13$ & $0.54 \mathrm{a} \pm 0.08$ & $0.92 \mathrm{~b} \pm 0.34$ & 0.047 \\
\hline \multirow[t]{2}{*}{ HDL \% } & 28 & $44.66 \mathrm{a} \pm 4.92$ & $36.96 \mathrm{a} \pm 9.09$ & $67.44 \mathrm{~b} \pm 4.16$ & 0.037 \\
\hline & 51 & $42.54 \mathrm{ab} \pm 4.98$ & $39.34 \mathrm{a} \pm 2.38$ & $45.06 \mathrm{~b} \pm 4.49$ & 0.035 \\
\hline$\overline{\mathrm{X}}$ & & $43.60 \mathrm{a} \pm 4.95$ & $38.15 \mathrm{a} \pm 5.74$ & $56.25 \mathrm{~b} \pm 4.37$ & 0.042 \\
\hline LDL & 28 & $1.14 \mathrm{~b} \pm 0.23$ & $1.92 \mathrm{~b} \pm 0.96$ & $0.32 \mathrm{a} \pm 0.48$ & 0.021 \\
\hline $\mathrm{mmol} \mathrm{l}^{-1}$ & 51 & $0.97 \pm 0.19$ & $0.88 \pm 0.24$ & $1.05 \pm 0.32$ & 0.063 \\
\hline$\overline{\mathrm{x}}$ & & $1.06 \mathrm{~b} \pm 0.21$ & $1.40 \mathrm{~b} \pm 0.60$ & $0.69 \mathrm{a} \pm 0.40$ & 0.038 \\
\hline
\end{tabular}

$\mathrm{a}, \mathrm{b}$ - values in the same rows with different letters differ significantly at $\mathrm{P} \leq 0.05$.

Table 6. Content of some biochemical parameters in plasma of piglets

\begin{tabular}{|c|c|c|c|c|c|}
\hline \multirow{2}{*}{ Item } & \multirow{2}{*}{$\begin{array}{c}\text { Day of } \\
\text { age }\end{array}$} & \multicolumn{3}{|c|}{ Feeding groups } & \multirow{2}{*}{ P-value } \\
\hline & & I & II & III & \\
\hline $\mathrm{TP}$ & 28 & $49.82 \mathrm{a} \pm 2.06$ & $56.92 \mathrm{~b} \pm 1.65$ & $55.22 \mathrm{~b} \pm 0.47$ & 0.033 \\
\hline $\mathrm{g} \mathrm{l}^{-1}$ & 51 & $42.62 \mathrm{a} \pm 1.53$ & $46.57 \mathrm{~b} \pm 2.51$ & $48.43 \mathrm{~b} \pm 2.95$ & 0.024 \\
\hline$\overline{\mathrm{x}}$ & & $46.22 \mathrm{a} \pm 1.80$ & $51.75 \mathrm{~b} \pm 2.08$ & $51.83 \mathrm{~b} \pm 1.71$ & 0.041 \\
\hline \multirow{2}{*}{$\begin{array}{l}\text { GLU } \\
\mathrm{mmol} \mathrm{1}^{-1}\end{array}$} & 28 & $7.74 \mathrm{a} \pm 0.24$ & $9.14 \mathrm{~b} \pm 0.14$ & $8.91 \mathrm{~b} \pm 0.53$ & 0.038 \\
\hline & 51 & $6.41 \pm 0.08$ & $6.65 \pm 0.48$ & $7.28 \pm 0.29$ & 0.085 \\
\hline$\overline{\mathrm{x}}$ & & $7.08 \mathrm{a} \pm 0.16$ & $7.90 \mathrm{~b} \pm 0.31$ & $8.10 \mathrm{~b} \pm 0.41$ & 0.046 \\
\hline \multirow{2}{*}{$\begin{array}{l}\text { UA } \\
\mu \mathrm{mol} \mathrm{l}^{-1}\end{array}$} & 28 & $55.46 \mathrm{~b} \pm 2.89$ & $32.48 \mathrm{a} \pm 1.30$ & $62.82 \mathrm{~b} \pm 1.86$ & 0.031 \\
\hline & 51 & $45.25 \mathrm{~b} \pm 1.68$ & $46.37 \mathrm{~b} \pm 2.40$ & $33.52 \mathrm{a} \pm 1.06$ & 0.025 \\
\hline$\overline{\mathrm{x}}$ & & $50.36 \mathrm{~b} \pm 2.29$ & $39.43 \mathrm{a} \pm 1.85$ & $48.17 \mathrm{~b} \pm 1.46$ & 0.039 \\
\hline \multirow{2}{*}{$\begin{array}{l}\text { UREA } \\
\mathrm{mmol} \mathrm{l}^{-1}\end{array}$} & 28 & $3.34 \mathrm{a} \pm 0.42$ & $3.32 \mathrm{a} \pm 1.01$ & $4.30 \mathrm{~b} \pm 1.28$ & 0.021 \\
\hline & 51 & $3.36 \pm 0.34$ & $3.39 \pm 0.59$ & $3.96 \pm 0.61$ & 0.084 \\
\hline$\overline{\mathrm{X}}$ & & $3.35 \mathrm{a} \pm 0.38$ & $3.36 \mathrm{a} \pm 0.80$ & $4.13 \mathrm{~b} \pm 0.95$ & 0.033 \\
\hline AST & 28 & $16.63 \mathrm{a} \pm 2.61$ & $18.83 \mathrm{a} \pm 0.97$ & $23.85 \mathrm{~b} \pm 6.03$ & 0.038 \\
\hline \multirow[t]{2}{*}{$\mathrm{U}^{-1}$} & 51 & $47.77 \mathrm{a} \pm 4.79$ & $57.79 \mathrm{~b} \pm 1.15$ & $45.36 \mathrm{a} \pm 4.68$ & 0.032 \\
\hline & & $32.20 \pm 3.70$ & $38.31 \pm 1.06$ & $34.61 \pm 5.36$ & 0.078 \\
\hline ALT & 28 & $46.31 \mathrm{~b} \pm 3.69$ & $31.93 \mathrm{a} \pm 1.55$ & $45.23 \mathrm{~b} \pm 22.70$ & 0.035 \\
\hline $\mathrm{U}^{-1}$ & 51 & $46.01 \mathrm{a} \pm 3.41$ & $61.26 \mathrm{~b} \pm 14.20$ & $48.91 \mathrm{a} \pm 4.33$ & 0.043 \\
\hline$\overline{\mathrm{x}}$ & & $46.16 \pm 3.55$ & $46.60 \pm 7.88$ & $47.07 \pm 13.52$ & 0.055 \\
\hline
\end{tabular}

$\mathrm{a}, \mathrm{b}$ - values in the same rows with different letters differ significantly at $\mathrm{P} \leq 0.05$. 
The percentage content of HDL-cholesterol and TG content in blood plasma of the piglets (in the entire experimental period) receiving a feed mixture supplemented with extruded rice (group II) were significantly lower than in the plasma of the animals from group III (Table 5). On day 28 of age and when comparing the mean content of LDL cholesterol in blood plasma, its significantly higher concentration was assayed in the piglets fed mixtures based on extruded rice supplemented with animal protein components (group III) compared to the other piglets (groups I and II) (Table 5).

Piglets receiving feed mixtures based on extruded rice (groups II and III) were characterized by significantly higher $(\mathrm{P} \leq 0.05)$ levels of total protein and glucose (except for day 51 of age) compared to those receiving the feed mixture with extruded wheat (group I).

There was no disparity in plasma level of urea assayed in this study and reference values described by Winnicka (2008). However, a significantly higher plasma level of urea (mean level and that measured on day 28 of age) was determined in the piglets fed the mixture based on extruded rice and with the addition of animal protein (group III), compared to the other animals under study (Table 6). Furthermore, both on day 28 and 51 of age, the activity of transaminases was subject to fluctuations depending on the experimental group (on day 28 the highest AST activity was determined in group III and ALT activity in groups I and III, whereas on day 51 the highest activities of AST and ALT were recorded in group II), but still no significant differences were demonstrated between groups (Table 6).

\section{Discussion}

Production effects of piglets are largely dependent on feed components. The observed increased body weight gains of piglets fed diets with extruded rice could be due to the barothermal pretreatment of rice that improved nutrient digestibility, which has been reported to significantly increase the morphological status of the gastrointestinal tract of the piglets after weaning and to have a positive impact on nutrient utilization (Vicente et al., 2009; Grela and Pastuszak, 2011). Zhen-Ping et al. (2008) and Pluske and Hampson (2005) demonstrated a high correlation between body weight at birth and rearing performance of piglets administered extruded ricebased feed mixture.

The feeding of piglets with mixtures based on extruded rice contributed to increased feed intake; however, the results obtained were different from observations made by Pluske and Hampson (2005), who noted that in the piglets fed mixtures based on traditional cereals, wheat in particular, the values of the feed conversion ratio were higher than in the animals fed diets with extruded rice. They explained this fact by a low energy intake from processed rice and by a lower concentration of crude fibre, which was reflected in poorer transformation of nutrients into body constituents.

The analysis of the effects of the increased content of animal-derived protein in feed should not be based only on production parameters. An important element 
of this analysis is the evaluation of the health status of animals. Investigations by Gralak et al. (2007) and Svoboda and Drabek (2002) prove that the most frequent cause of a reduced number of erythrocytes is anaemia induced by a low level of iron in the body. In turn, Czech et al. (2003) point to a close correlation between the age and growth rate and deficiency of this element. Therefore, in view of the contemporary intensification of fattening, the administration of iron-containing preparations to piglets seems indispensable. The introduction of protein components of animal origin to a feed mixture for piglets (group III) was expected to improve the erythrocyte markers, which was attributed to their beneficial effect on production stress attenuation as well as reduced morbidity and mortality rates amongst piglets. This was, however, not confirmed in the reported experiment. A study by Chang et al. (2012) demonstrates that the use of protein feedstuffs containing $60.0 \%$ cottonseed meal, $12.5 \%$ blood meal, $12.5 \%$ feather meal, $10.0 \%$ wheat bran, and $5.0 \%$ corn in feed mixtures for pigs contributed to a reduced count of $E$. coli bacteria and an increased count of lactic acid bacteria in faeces.

The correct number of lymphocytes in blood of the piglets from all groups suggests the well-balanced amino acid composition, especially of glutamine (Pawłowska, 2007; Zou et al., 2006). In piglets fed a mixture with extruded rice analyses showed an increased number of immune cells (lymphocytes). According to Carroll et al. (2002) and Frank et al. (2003), the administration of dried blood plasma preparations to piglets increases their immunity by reinforcing the first line of body defense against bacteria, viruses and protozoa. Owing to these properties the blood preparation may play a similar function as antibiotics in animal feeding, but without posing such a risk as they do (Torrallardona et al., 2002). The insignificant increase in the number of lymphocytes observed in the piglets may be explained by stressogenic factors, e.g. the catching of piglets as emphasized by Czech et al. (2003).

According to Bikker et al. (2004), the animal protein components (including dried blood plasma) used in mixtures for piglets have positive effects on feed conversion ratio and, by influencing immunity increase, also on the improvement of nutrient metabolism. In addition, they can contribute to the regulation of lipid profile markers. Results of our study suggest that piglets fed the mixture with the increased content of animal protein were characterized by an increased percentage of HDL cholesterol and reduced content of LDL cholesterol. Rekiel (2008) reports that an increase in HDL cholesterol along with a decreasing level of total cholesterol is feasible owing to the administration of non-digestible oligosaccharides. Out of the biochemical blood markers analysed in the study, the key ones include protein and glucose. A study by Fijałkowski et al. (2008) demonstrates explicitly a negative correlation between the age and total protein level in blood of piglets, which has been confirmed in our experiment.

Results of urea content in the blood of piglets are consistent with observations made by Pluske and Hampson (2005), who reported that the addition of extruded rice resulted in the increased urea concentration, compared to the animals fed diets based on commonly applied cereals. Bakuła et al. (2007) suggests that the increase in urea level is due to the improper adjustment of extrusion parameters, i.e. pressure and temperature. Upon incorrect grain processing, protein administered to piglets is 
not completely utilized. Considering that the level of urea depends on, e.g., protein content of the feed mixture, the higher concentration of urea in blood plasma of piglets from group III may be explained by a high content of protein in the administered feed mixtures with the simultaneously low utilization of this protein. This correlation was confirmed by results of uric acid content assay.

As claimed by Bakuła et al. (2007), the activities of AST and ALT are sensitive indicators of the incidence of pathological conditions. Also according to Mikulska-Skupień et al. (2007), excessive levels of AST and ALT are indicative of internal organs damage. No such changes were observed in our experiment.

The results obtained in the study indicate that the addition of extruded rice and high doses of animal protein to feed mixtures for piglets improved their rearing performance (higher body weight gains and higher feed conversion ratio).

Feeding the piglets with the feed mixtures containing extruded rice and the increased content of animal protein (III group) was also observed to stimulate lipid metabolism, which resulted in the reduced levels of LDL cholesterol in blood plasma as well as in increased percentage of HDL cholesterol, which contributed to increased blood levels of urea compared to the remaining experimental groups.

In summary, it may be concluded that the concurrent administration of dried blood plasma and extruded rice may occupy a significant place in piglet feeding, above all as a component improving production results and stimulating the health status of the animals.

\section{References}

B akuła T., Obremski K., Iwaniuk Z., Ordyński Z., Wiese I., Kołodziej K. (2007). Efficacy of feed containing broth and fish oil in piglet rearing performance. Med. Weter., 63 (10): 1234-1238.

Bikker P., van Dijk A.J., Dirkzwager A., Fledderus J., Ubbink-Blanksma M., B eynen A.C. (2004). The influence of diet composition and anti-microbial growth promoter on the growth response of weaned piglets to spray dried animal plasma. Livest. Prod. Sci., 86: 201-208.

Carroll J.A., Tou chette K.J., M at teri R.L., D y e r C.J., A 11 e e G.L. (2002). Effect of spray dried plasma and lipopolysaccharide exposure on weaned pigs: II. Effects on the hypothalamicpituitary-adrenal axis of weaned pigs. J. Anim. Sci., 80: 502-509.

Chang J., Y in Q., Wang P., Wang W., Zu o R., Zheng Q., L i u J. (2012). Effect of fermented protein feedstuffs on pig production performance, nutrient digestibility, and fecal microbes. Turk. J. Vet. Anim. Sci., 36 (2): 143-151.

Czech A., Orlicki Ł., Krasucki W., Truchliński J., Matras J., Grela E.R. (2003). Efficacy of injected or orally administered ferric preparation in rearing piglets. Annales UMCS Lublin - Polonia, sect. EE, 21: 207-213.

Fijałkowski K., Furowicz A., Czernomysy-Furowicz D., Silecka A. (2008). Serum fraction analysis of healthy piglets in the neonatal period. Acta Sci. Pol. ser. Zootechnica, 7 (2): $3-10$.

Frank J.W., Carroll J.A., A 11 e e G.L., Z a nne 11 i M.E. (2003). The effects of thermal environment and spray-dried plasma on the acute-phase response of pigs challenged with lipopolysaccharide. J. Anim. Sci., 81: 1166-1176.

Friedewald W.T., Levy R.I., Fredrickson D.S. (1970). Estimation of the concentration of low-density lipoprotein cholesterol in plasma, without use of the preparative ultracentrifuge. Clin. Chem., 18 (6): 499-502. 
Friendship R.M., Henry S.C. (1996). Cardiovascular system, haematology and clinical chemistry. (In:) Diseases of Swine, Leman A.D., Straw B.E., Mengeling W.L., D’Allaire S., Taylor D.J. (eds). Iowa State Univ. Press, USA, pp. 3-11.

Gra lak M.A., Li piński P., Starzyński R.R., S muda E., Kurył T., D ębski B. (2007). Influence of iron-dextran treatment on hepatic mineral elements content in new born piglets. Med. Weter., Supl. 63 (11): 1500-1503.

Gre la E.R., P a s t u s z a k J. (2011). Effect of extrusion-cooking of some grain species on piglet performance and blood lipid profile. Annales UMCS Lublin - Polonia, sect. EE, 29: 39-45.

Klem T.B., B leken E., M orberg H., Thoresen S.I., Framstad T. (2010). Hematologic and biochemical reference intervals for Norwegian crossbreed grower pigs. Vet. Clin. Path., 39 (2): 221-226.

L a r s o n M.R., D o n ov a n S.M., P o tte r S.M. (1996). Effects of dietary protein source on cholesterol metabolism in neonatal pigs. Nutr. Res., 16 (9): 1563-1574.

Mikulska-Skupień E., Procajło Z., Platt-Samoraj A., Terech-Majewska E., S i e mion e k J., S zw e d a W. (2007). Hematological and biochemical indices in pigs following infection with Herpes virus suis type 1. Med. Weter., 63 (1): 90-94.

NRC (1998). Nutrient Requirements of Swine. Tenth Rev. Ed., Washington, DC.

$\mathrm{P}$ a w $ł$ o w s k a M. (2007). The influence L-alanyl-L-glutamine on structure and mineralization in femur of piglets. Acta Sci. Pol.-Med. Veter., 6 (1): 21-30.

Peiniau J., A u maitre A., Le breton Y. (1996). Effects of dietary protein sources differing in solubility on total tract and ileal apparent digestibility of nitrogen and pancreatic enzymes activity in early weaned pigs. Livest. Prod. Sci., 45: 197-208.

Plus k e J., Hamps on D. (2005). Rice based diets in pigs for protection against intestinal bacterial infections. RIRDC Publication No. 05/143. Rural Ind. Res. Dev. Corp., Kingston ACT, Australia.

Rekiel A. (2008). Effect of probiotic on the biochemical parameters in blood of fatteners. Med. Weter., 64 (1): 110-112.

S v o b od a M., D rabe k J. (2002). Effect of oral administration of iron microemulsion on the erythrocyte profile of suckling piglets in comparison with parenteral application of iron dextran. Czech J. Anim. Sci., 47 (6): 213-218.

Torrallardona D., Conde R., Esteve-Garcia R., Brufau J. (2002). Use of spray dried animal plasma as an alternative to antimicrobial medication in weanling pigs. Anim. Feed Sci. Technol., 99: 119-129.

Vente-Spreeuwe nberg M.A.M., Verdonk J.M.A.J., B akker G.C.M., B e ynen A.C., Vers t e g e n M.W.A. (2004). Effect of dietary protein sources on feed intake and small intestinal morphology in newly weaned piglets. Livest. Prod. Sci., 86: 169-177.

Vicente B., Valencia D.G., Pérez-Serrano M., Lázaro R., Ma teos G.G. (2008). The effects of feeding rice in substitution of corn and the degree of starch gelatinization of rice on digestibility of dietary components and productive performance of young pigs. J. Anim. Sci., 86: $119-126$.

Vicente B., Valencia D.G., Pérez-Serrano M., Lázaro R., M a teos G.G. (2009). Effects of feeding rice and the degree of starch gelatinisation of rice on nutrient digestibility and ileal morphology of young pigs. Br. J. Nutr., 101: 1278-1281.

Winnicka A. (2008). Reference values of basic laboratory tests in veterinary science (in Polish). Third revised and expanded edition, SGGW, Warszawa.

Zhen-Ping H., Yu-Long Y., Rui-Lin H., Tie-Jun L., Rongqing H., Yulan L., Xin W., Zhiqiang L., Wence W., Hua X., Guo-yao W., Li ang-Xi T. (2008). Rice protein concentrate partially replaces dried whey in the diet for early-weaned piglets and improves their growth performance. J. Sci. Food Agr., 88: 1187-1193.

Z o u X.T., Z h e n g G.H., F a n g X.J., J i a n g J.F. (2006). Effects of glutamine on growth performance of weanling piglets. Czech J. Anim. Sci., 51 (10): 444- 448. 